\title{
Biodiesel Production from a Mixture of Rubber Seed Oil and Waste Oil Through the Alcoholysis Process with Catalysts Based on Vegetable Waste
}

\author{
I Ibrahim, A M Syam, M Muhammad, Z Ginting*, S Maliki \\ Department of Chemical Engineering, Universitas Malikussaleh, Aceh, Indonesia \\ Corresponding author E-mail: zginting@unimal.ac.id
}

Manuscript received 15 August 2021; revised 1 Sept 2021; accepted 15 Sept 2021. Date of publication 4 Nov 2021

\begin{abstract}
The increasing types of people needs along with the times have resulted in the need for energy increasing so that the supply of energy, especially energy that cannot be renewed (unrenewable energy) is decreasing. Currently, almost $80 \%$ of the world's energy needs are met by fossil fuels. In fact, the use of fossil fuels can cause global warming. To reduce dependence on fossil fuels as an energy source, it is necessary to search for energy sources that can be used as alternative fuels that are environmentally friendly. Indonesia is an agricultural country that is overgrown with plantation crops that produce various kinds of waste such as rubber seeds which contain oil. This plant produces a lot of wasted seeds that are not useful. Therefore, researchers want to research the oil from rubber seeds to be a biodiesel product and in order to get high quality results. This study regulates several independent variables, namely the alcoholysis temperatures: 650C, $700 \mathrm{C}$ and $750 \mathrm{C}$ and the alcohol volume: $200 \mathrm{ml}, 250 \mathrm{ml}$ and $300 \mathrm{ml}$. The process is carried out by extraction using the alkolysis method. The best yield yielded $60.5 \%$, with the best yield of biodiesel from alcoholysis obtained at a volume of $250 \mathrm{ml}$ of ethanol and a temperature of $750 \mathrm{oC}$ with a density of $09 \mathrm{~kg} / \mathrm{m} 3$ and a viscosity of $3,285 \mathrm{~mm} 2 / \mathrm{s}(\mathrm{cSt})$, fulfilling the requirements of SNI 7182:2015. Based on the results of GC analysis, the main fatty acid components in the sample were at peak 1, namely saturated fatty acids in the form of palmitic acid at $44,28 \%$ and peak 4 , namely unsaturated fatty acids in the form of oleic acid at $31.99 \%$.
\end{abstract}

Keywords: Biodiesel, Rubber Seed Oil, Alcoholysis, Bio-catalyst

\section{Introduction}

Biodiesel compounds are one of the alternative fuels that are environmentally friendly because biodiesel can reduce carbon monoxide (CO) gas emissions by about $50 \%$, carbon dioxide gas $(\mathrm{CO} 2)$ by about $78.45 \%$ and free sulfur content [1] [2]. Biodiesel compounds can be obtained from plant oils derived from renewable resources such as vegetable oil from rubber seeds and used cooking oil (cooking oil) through esterification and/or transesterification with alcohol and the help of a catalyst. Biodiesel compounds are known as renewable resources because they can generally be extracted from various agricultural and plantation products. Vegetable oils commonly used for biodiesel production include castor seed oil, palm oil, rubber seed oil and so on. One alternative raw material that deserves to be studied is rubber seed oil [3] [4].

Raw materials that have the potential as raw materials for making biodiesel compounds include palm oil, soybeans, jatropha, kapok and several other plant species. The manufacture of biodiesel compounds is generally carried out using homogeneous base catalysts such as $\mathrm{NaOH}$ and $\mathrm{KOH}$ because they have a higher catalytic ability than other catalysts [5]. This research is limited to the alcoholysis reaction which involves several variables and then analyzes the resulting biodiesel compounds such as density, viscosity, yield and analysis of the composition of hydrocarbon compounds using GC (Gas Chromatography) [6] [7].

\section{Literature Review}

\subsection{Rubber seed ( Hevea Brasiliensis)}

Seeds that have been processed by the community are usually for oil. Rubber seed oil can be used as a lubricant, but it can also be used as a mixture to make paint. Processing rubber seeds into oil inevitably produces waste. The waste is usually used for plant fertilizer, but it can also be used as animal feed. According to Swern, 1964 in the journal Novia fresh rubber seeds consisted of 34.1\% skin, $41.2 \%$ content and $24.4 \%$ water, while rubber seeds that had been dried for two days consisted of $41.6 \%$ skin, $8 \%$ water, $15.3 \%$ oil and $35.1 \%$ 
dry matter [8]. Rubber seeds contain $40 \%$ to $50 \%$ oil consisting of $17 \%$ to $22 \%$ saturated fatty acids and $77 \%$ to $82 \%$ unsaturated fatty acids [9]. For the nutritional content contained in rubber seeds and needed by the body, based on test results at the Pontianak Research and Industrial Standardization Center (Baristand), rubber seeds contain 40.9\% fat, 15.6\% protein, and 31.6\% carbohydrates. For the nutritional content contained in rubber seeds and needed by the body, based on test results at the Pontianak Research and Industrial Standardization Center (Baristand), rubber seeds contain 40.9\% fat, 15.6\% protein, and 31.6\% carbohydrates [10] [11].

The rubber seed waste oil used in this study contains high free fatty acids, namely $97.77 \%$ and has a high acid number which is equivalent to $6.2 \mathrm{mg} \mathrm{KOH} \mathrm{g}$ of oil, so esterification is necessary to reduce the free fatty acid content to ester. Methanol (20\% oil volume) was reacted with rubber seed waste oil with $98 \%$ sulfuric acid catalyst $(0.5 \%$ oil volume) to become ester.

\subsection{Biodiesel Compound}

Biodiesel compounds are monobiodiesel from long-chain fatty acids contained in vegetable oils or animal fats to be used as fuel for diesel engines. Biodiesel compounds can be obtained through a triglyceride transesterification reaction or a free fatty acid esterification reaction depending on the quality of the vegetable oil used as raw material. Biodiesel compounds are the most appropriate solution to replace fossil fuels as the world's main transportation energy source, because biodiesel compounds are renewable fuels that can replace petrol diesel in engines and can be transported and sold using current infrastructure. Biodiesel compounds are biodegradable, contain almost no sulfur and are renewable fuels. Alternative fuels consist of methyl or ethyl esters, either transesterified from triglycerides (TG) or esterified from free fatty acids (FFA) [12] [13].

Biodiesel compound fuels are becoming more attractive because of their environmental benefits. Plants and vegetable oils and animal fats are renewable sources of biomass [14]. Currently, most biodiesel compounds arise from the transesterification of edible resources, such as animal fats, vegetable oils and even waste cooking oil, by alkaline catalyzed processes. However, high consumption of catalyst causes soap formation and low conversion of biodiesel compounds [15] [16].

Transesterification is a process that reacts triglycerides in vegetable oils or animal fats with short chain alcohols such as methanol or ethanol (currently most of the biodiesel production uses methanol) to produce fatty acid methyl esters (FAME) or biodiesel and glycerol compounds. (glycerin) as a by-product. The catalyst used in the transesterification process is a base/alkali, usually sodium hydroxide $(\mathrm{NaOH})$ or potassium hydroxide $(\mathrm{KOH})[17]$.

\subsection{Alcoholic Reaction}

The alcoholysis process is a method in which the extraction process is carried out separately. In the alcoholysis reaction, the oil extraction process and the transesterification reaction of oil into biodiesel compounds occur simultaneously in one process. Alcoholysis is a method developed to produce mono esters from oils containing high free fatty acids. In alcoholysis, the oil extraction process and the esterification reaction are carried out simultaneously. Alcohol in this method functions as a solvent, oil components and as a reagent in the esterification reaction. The use of this method in the production of biodiesel compounds can reduce costs because the conventional oil esterification step is removed [18] [19].

Alcoholysis is a simpler step in producing biodiesel compounds by eliminating the oil extraction and refining process so as to reduce the cost of producing biodiesel compounds [20]. The alcoholysis method is a method where the extraction and transesterification processes are not carried out separately, the oil extraction process and the transesterification reaction of oil into biodiesel compounds occur simultaneously in one process. This method utilizes triglycerides derived from oil source raw materials without the need to extract and purify them first [21] [22].

\subsection{Catalyst Based on Waste Vegetable}

Esterification and transesterification processes in the formation of biodiesel are very necessary catalysts. The function of the catalyst is to speed up the process, it turns out that natural ingredients from vegetable ingredients that contain organic compounds provide benefits to be used as catalysts. One of these vegetable ingredients is banana weevil. Banana weevil is mostly obtained as agricultural waste which is organic material left over from banana plants that is not utilized. Banana bole can be used as the main ingredient in composting because it contains complete macro and micro nutrients [23] [4]. The nutrient content of banana weevil includes nitrate, ammonrum, zinc, manganese, cupium, phosphate, potassium, calcium, iron, and carbon [7] [22].

\section{Methods}

Research tools and materials used in research extraction, distillation, and other supporting equipment. As for the materials used in rubber seed research, alcohol, catalysts, $n$-hexane, etc. The variables in this study were varying the alcoholation temperature, namely 65,70 , and $750 \mathrm{C}$ and the alcohol volume was 200, 250 and $300 \mathrm{ml}$ [24].

In this study, the working procedure for the manufacture of biodiesel from rubber seed oil and waste oil with alcoholysis is divided into several stages including raw material preparation, alcoholysis process, separation process, density analysis, viscosity analysis, yield analysis, and analysis of the composition of hydrocarbon compounds using gas chromatography. For other variables, it will be carried out with the same steps but by changing the temperature and solvent volume variables according to what has been determined. Furthermore, analysis of yield, density, viscosity, and analysis of biodiesel compounds was carried out [25].

\section{Results and Discussion}

\subsection{Rubber Seed Oil Yield}

After the process of extracting rubber seed oil from the seeds, it was carried out using n-hexane solvent at constant conditions and solvents. Then a series of separation processes were carried out to obtain the yield as at $60.5 \%$. 
Table 1. Data from Research on Density and Viscosity Measurement

\begin{tabular}{ccccc}
\hline Temperature $\left({ }^{0} \mathrm{C}\right)$ & Volume $(\mathrm{ml})$ & Density $\left(\mathrm{kg} / \mathrm{m}^{3}\right)$ & Viscositas $(\mathrm{cP})$ & Yield $(\%)$ \\
\hline \multirow{2}{*}{65} & 200 & 0,850 & 4,466 & 59.07 \\
& 250 & 0,870 & 3,547 & 60.10 \\
& 300 & 0,880 & 3,029 & 59.88 \\
\hline \multirow{2}{*}{70} & 200 & 0,870 & 4,355 & 60.00 \\
& 250 & 0,885 & 3,436 & 55.96 \\
& 300 & 0,890 & 2,328 & 59.09 \\
\hline \multirow{2}{*}{75} & 200 & 0,880 & 3,742 & 57.03 \\
& 250 & 0,900 & 3,285 & 60.50 \\
& 300 & 0,895 & 2,276 & 58.84 \\
\hline
\end{tabular}

\subsection{Effect of Alcohol Volume and Operating Temperature on}

According to the procedure for carrying out the alcoholysis process, the results are presented in Table 1. If we look at Figure 1 of the results of the density test on the effect of alcohol volume and temperature, it shows that the volume and temperature increase and density increases, only at a volume of $300 \mathrm{ml}$ and a temperature of $75 \mathrm{oC}$ it slightly decreases. These results indicate that all results are within the standard range of SNI 7182:2015 for biodiesel. Based on the working procedure, it is shown that the alcohissis process is going well, it is estimated that there is a transesterification reaction that takes place to form methyl esters which are the basic ingredients of biodiesel. In addition, in the previous extraction process there was a role for $\mathrm{n}$-hexane which first took the rubber seed oil better than the seeds. The distillation process for the separation of alcohol as the final stage also plays a perfect role.

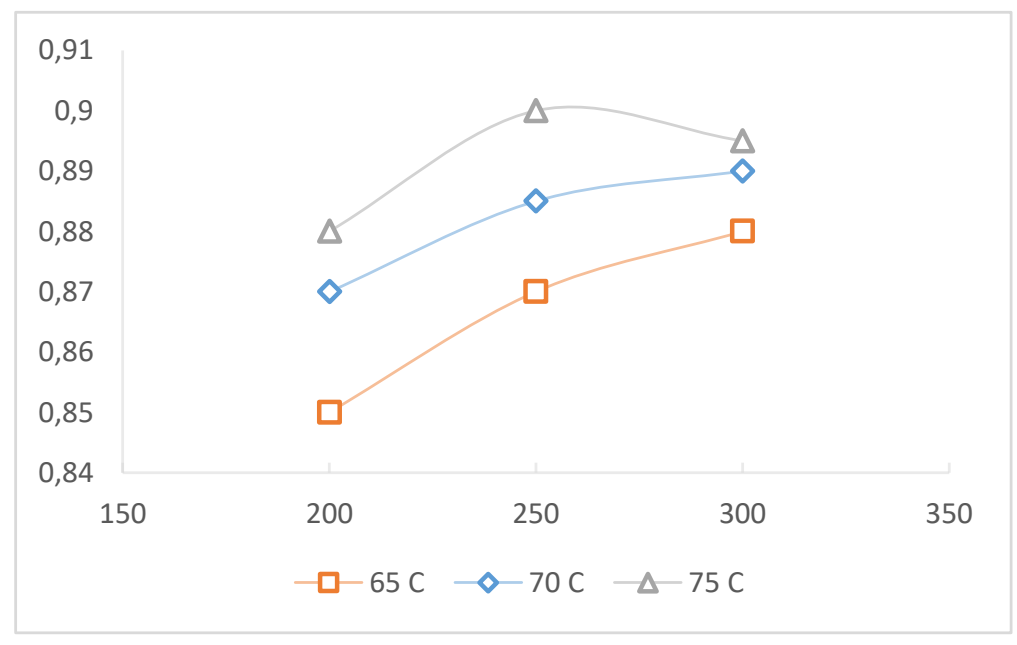

Fig 1. Effect of Alcohol Volume and Temperature on Density

\subsection{Effect of Alcohol Volume and Operating Temperature on Viscosity}

According to the test results obtained indicate that the increase in the volume of alcohol in the alcoholysis process causes a decrease in viscosity. Furthermore, the increase in process temperature causes a decrease in viscosity as illustrated in Figure 2 . This occurs because the increase in the volume of alcohol provides a greater chance of contact between oil and alcohol in the same operating time, while the increase in viscosity temperature decreases because the high temperature for the fluid can dilute it. solution. In addition, the alcoholysis process provides a good opportunity for the formation of esters under the operating conditions. If we look at table 1 shows.

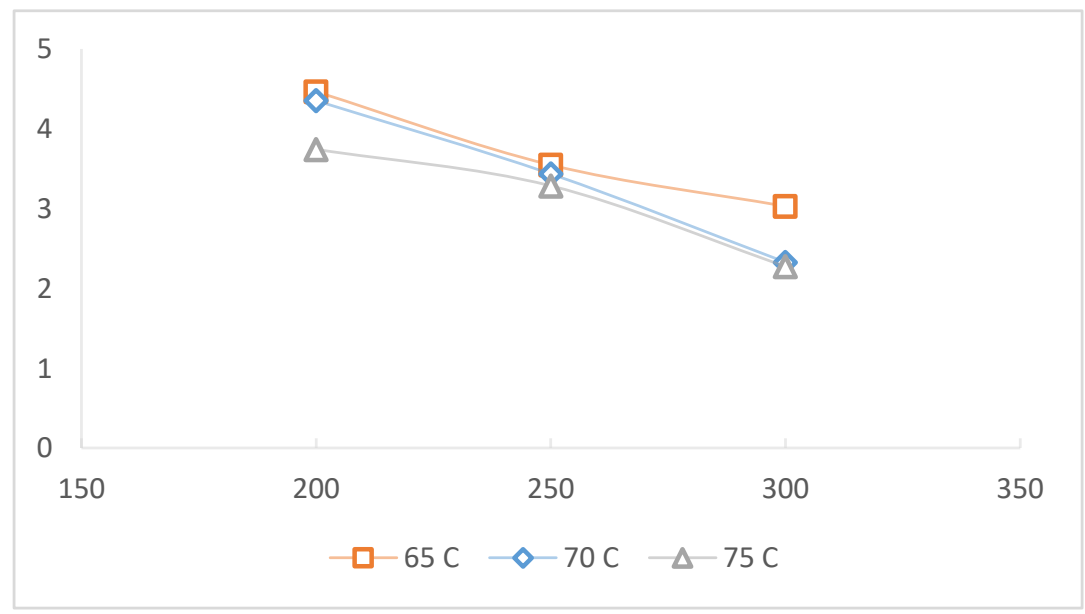

Fig 2. Effect of Alcohol Volume and Temperature on Viscosity 


\subsection{Analysis of Biodiesel Compound Composition}

Methyl ester from rubber oil transesterification into biodiesel was analyzed using Gas Chromatography-Mass Spectroscopy (GC-MS). This analysis is a qualitative and quantitative analysis that can be used to determine the type of fatty acid content in biodiesel and its quantity. Methyl ester biodiesel which has been analyzed by GC-MS shows five dominant peaks as presented in Figure 3.

Figure 3 is a chromatogram of biodiesel composition analysis using GC-MS. The chromatogram shows that the biodiesel in this study contains methyl esters which match the fatty acids contained in used cooking oil. However, methyl laurate does not appear in biodiesel, such as lauric acid in used cooking oil. It is possible that methyl laurate was also formed, but the instrument could not read it because there were too high content of compounds such as methyl oleate, linoleate and palmitate, so that methyl laurate was not observed because the content was too small. Based on the results of GC analysis, the main fatty acid component in the sample was at peak 1, namely saturated fatty acids in the form of palmitic acid at $44,28 \%$ and peak 4 , namely unsaturated fatty acids in the form of oleic acid, at $31.99 \%$.

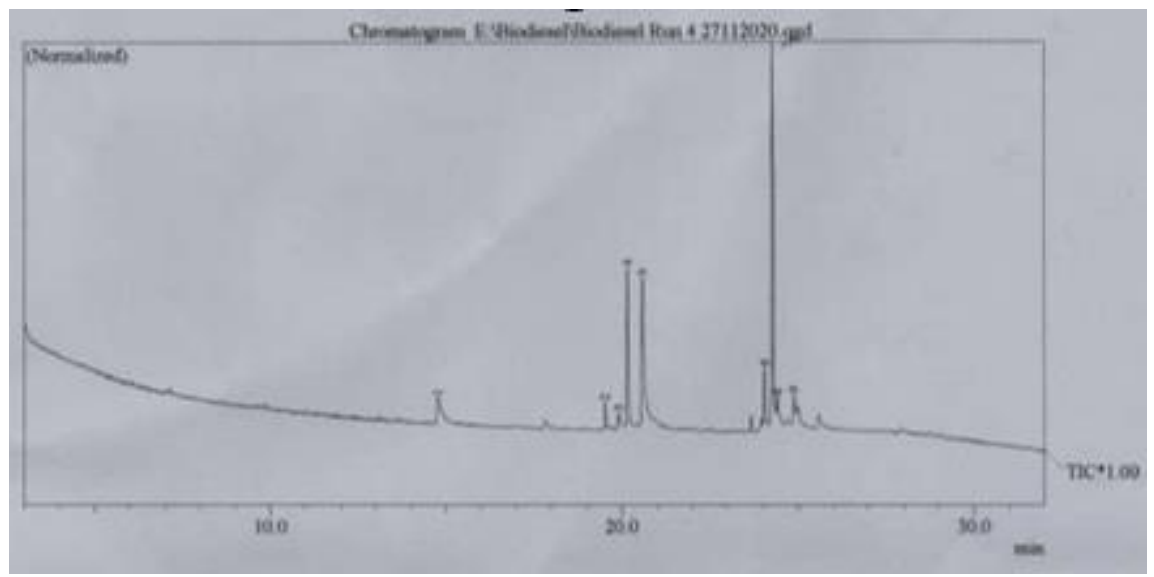

Fig 3. Product Test Results with GC-MS

\section{Conclusion}

Based on the results of the study, it can be concluded that crude rubber seed oil and waste oil using alcoholysis process with banana weevil catalyst to produce biodiesel. The best results were at $60.5 \%$ pen, with the best yields of biodiesel from alcoholysis obtained at a volume of $250 \mathrm{ml}$ of ethanol and a temperature of $75 \mathrm{oC}$, namely a density of $09 \mathrm{~kg} / \mathrm{m} 3$ and a viscosity of $3,285 \mathrm{~mm} 2 / \mathrm{s}(\mathrm{cSt})$, fulfilling the requirements of SNI 7182:2015. Based on the results of GC analysis, the main fatty acid component in the sample was at peak 1, namely saturated fatty acids in the form of palmitic acid at $44,28 \%$ and peak 4 , namely unsaturated fatty acids in the form of oleic acid, at $31.99 \%$.

\section{References}

[1] yudhistiar maulana, "PENGARUH LUAS LAHAN, JUMLAH PRODUKSI DAN HARGA TANDAN BUAH SEGAR (TBS) KELAPA SAWIT TERHADAP NILAI PDRB SUB SEKTOR TANAMAN PERKEBUNAN DI KALIMANTAN BARAT," $J$. Curvanomic, 2019.

[2] M. Zarebnia and R. Parvaz, “A new approach for solution of telegraph equation,” Int. J. Nonlinear Anal. Appl., vol. 12, no. 1, 2021, doi: 10.22075/ijnaa.2021.4811.

[3] D. Riyan Rizaldi, E. Nurhayati, Z. Fatimah, and Z. Amni, "The Importance of Parental Assistance in Supervising the Use of Technology for Children During the Home Learning Program," Int. J. Eng. Sci. Inf. Technol., vol. 1, no. 3, 2021, doi: 10.52088/ijesty.v1i3.78.

[4] E. Azroul and F. Balaadich, "Quasilinear elliptic systems in perturbed form," Int. J. Nonlinear Anal. Appl., vol. 10, no. 2, 2019, doi: 10.22075/ijnaa.2019.19034.2050.

[5] R. Maulida, "BIODIESEL MINYAK BIJI PEPAYA (Carica papaya L.) MELALUI PROSES TRANSESTERIFIKASI KULIT TELUR," vol. 5, no. 2252, 2016.

[6] N. Sylvia, Y. Yunardi, H. Husni, and A. Muslim, "Simulation of CO2 Gas Adsorption Process Flow at Cyclone Gas Outlet in Palm Oil Mills Using Computation Fluid Dynamic Simulation," Int. J. Eng. Sci. Inf. Technol., vol. 1, no. 3, 2021, doi: 10.52088/ijesty.v1i3.112.

[7] G. Zabandan, "Several integral inequalities and their applications on means," Int. J. Nonlinear Anal. Appl., vol. 12, no. 2, 2021, doi: 10.22075/ijnaa.2021.23169.2486.

[8] H. Yuliyati and R. Yuliandhika, "PEMANFAATAN BIJI KARET SEBAGAI SEMI DRYING OIL DENGAN METODE EKSTRAKSI MENGGUNAKAN PELARUT N-HEKSANA,” vol. 16, no. 4, pp. 1-10, 2009.

[9] S. Fauzi and S. Bahruddin, "Pembuatan Biodiesel dari Minyak Biji Karet Menggunakan Reaktor Membran," pp. 1-6, 2012.

[10] E. Kalsum, Y. Purnomo, and T. W. Caesariadi, "IDENTIFIKASI PEMANFAATAN AIR BERSIH DI PERMUKIMAN PERKOTAAN (STUDI KASUS KELURAHAN SUNGAI BANGKONG KOTA PONTIANAK)," LANGKAU BETANG J. Arsit., 2017, doi: 10.26418/lantang.v4i2.23250.

[11] Z. Azmi, "Artificial Neural Network Model For Wind Mill," Int. J. Eng. Sci. Inf. Technol., vol. 1, no. 3, 2021, doi: 10.52088/ijesty.v1i3.84

[12] J. Van Gerpen, B. Shanks, R. Pruszko, and D. Clements, "Biodiesel Analytical Methods Biodiesel Analytical Methods," no. August 2002, 2004.

[13] R. Y. Widya Baskara, A. Wahyuni, and F. Hardanignrum, "The Effect Of Road Narrowing On The Traffic Characteristics,” Int. J. Eng. Sci. Inf. Technol., vol. 1, no. 2, 2021, doi: 10.52088/ijesty.v1i2.54.

[14] D. D. Mclean, "Acid-catalyzed production of biodiesel from waste frying oil," vol. 30, pp. 267-272, 2006, doi: 10.1016/j.biombioe.2005.10.004. 
[15] M. J. Haas, A. J. Mcaloon, W. C. Yee, and T. A. Foglia, “A process model to estimate biodiesel production costs,” vol. 97, pp. 671678, 2006, doi: 10.1016/j.biortech.2005.03.039.

[16] R. Nasimi, S. Azadi, M. Farzinfar, and M. Jazaeri, "A novel approach to estimate reservoir permeability using machine learning method," Int. J. Nonlinear Anal. Appl., vol. 12, no. Special Issue, 2021, doi: 10.22075/ijnaa.2021.4918.

[17] R. Candra Fitrian and A. Sumarno, "Study of the Effect Clay Substitution with Wood Sawdust and Hydroton on Compressive Strength, Density and Water Absorption of Red Brick Case Study of Traditional Red Brick Industry in Singgahan Village," Int. J. Eng. Sci. Inf. Technol., vol. 1, no. 1, 2021, doi: 10.52088/ijesty.v1i1.103.

[18] S. Biodisel et al., "Ratna Dewi Kusumaningtyas dan Achmad Bachtiar," vol. 1, no. 2, pp. 9-18.

[19] S. Baqaruzi, A. Afit Miranto, and D. Wahyuda, "The Effect of Halbach Array Configuration on Permanent-Magnet Synchronous Generator (PMSG) Outer-Runner," Int. J. Eng. Sci. Inf. Technol., vol. 1, no. 2, 2021, doi: 10.52088/ijesty.v1i2.50.

[20] M. J. Haas, K. M. Scott, W. N. Marmer, and T. A. Foglia, "In situ Alkaline Transesterification : An Effective Method for the Production of Fatty Acid Esters from Vegetable Oils," vol. 81, no. 1, pp. 83-89, 2004.

[21] J. Qian, F. Wang, S. Liu, and Z. Yun, "Bioresource Technology In situ alkaline transesterification of cottonseed oil for production of biodiesel and nontoxic cottonseed meal," vol. 99, pp. 9009-9012, 2008, doi: 10.1016/j.biortech.2008.04.059.

[22] B. Dwi Cahyono and D. Sulastri, "Development Of Electrical Installation Learning Me-dia With Delphi Language,” Int. J. Eng. Sci. Inf. Technol., vol. 1, no. 3, 2021, doi: 10.52088/ijesty.v1i3.81.

[23] S. A. Bahtiar et al., "PEMANFAATAN KOMPOS BONGGOL PISANG (Musa acuminata) UNTUK MENINGKATKAN PERTUMBUHAN DAN KANDUNGAN GULA TANAMAN JAGUNG MANIS ( Zea mays L . Saccharata ) Agritrop Jurnal IlmuIlmu Pertanian," vol. 1, pp. 18-22.

[24] S. S. O. Alnaqbi and S. S. Omar, "Smart educational system to enhancing students performance through teachers efficiency in the United Arab Emirate," Int. J. Nonlinear Anal. Appl., vol. 11, no. Special Issue, 2020, doi: 10.22075/IJNAA.2020.4606.

[25] N. Ghaderi and S. Shams, "Stability for comprehensive classes of analytic functions," Int. J. Nonlinear Anal. Appl., vol. 11, no. 2, 2020, doi: 10.22075/ijnaa.2018.16662.1887. 